\title{
PENGARUH DISIPLIN KERJA TERHADAP KINERJA GURU PADA TAMAN KANAK-KANAK METHODIST PEMATANGSIANTAR
}

\author{
Oleh: \\ Ester Rumata Chatrina Tobing \\ S1 Manajemen \\ Darwin Lie, Parman Tarigan, Liper Siregar
}

Abstraksi

Rumusan masalah dalam penelitian ini adalah bagaimana pengaruh disiplin kerja dan kinerja guru pada Taman Kanak-kanak Methodist Pematangsiantar. Penulis menggunakan desain penelitian yaitu penelitian lapangan dan penelitian kepustakaan. Populasinya adalah guru Taman Kanak-kanak Methodist Pematangsiantar dengan jumlah 17 orang. Metode pengumpulan data dengan wawancara, dokumentasi, kuesioner yang bersumber dari sumber data primer dan sekunder dan dianalisa dengan analisa deskriptif kualitatif dan analisa deskriptif kuantitatif.

Hipotesis penelitian adalah disiplin kerja memberikan pengaruh yang positif terhadap kinerja guru pada Taman Kanak-kanak Methodist Pematangsiantar. Untuk mengukur kinerja guru (Y) dan disiplin kerja (X) penulis menyebarkan kuesioner kepada guru-guru TK sehingga diperoleh data deskriptif kualitatif dan deskriptif kuantitatif. Hasil analisis menunjukkan pengaruh positif variabel $\mathrm{X}$ terhadap variabel $\mathrm{Y}$ dengan persamaan $\hat{Y}=15,30+0,7711 X$. Kekuatan hubungan kedua variabel adalah sangat kuat yaitu sebesar 0,848. Dari koefisien determinasi dapat dijelaskan $71,9 \%$ kinerja guru dijelaskan oleh disiplin kerja dan $28,1 \%$ dijelaskan oleh faktor lain yang tidak dibahas dalam penelitian ini. Dari hasil pengolahan dan perhitungan data kuesioner, Penulis menyimpulkan bahwa disiplin kerja yang diterapkan sekolah berpengaruh menciptakan kinerja guru. Hal ini dibuktikan secara matematis melalui uji hipotesis, dimana hasil uji $t_{\text {hit }}(5,25)>t_{\text {tab }}(2,131)$. Kinerja guru selalu harus ditingkatkan, untuk itu diperlukan usaha penerapan disiplin kerja secara terus menerus.

Kata Kunci: Disiplin Kerja dan Kinerja Guru

\section{Abstraction}

As for internal issue formula in this research is how influence of discipline work and teacher performance at Nursery School of Methodist Pematangsiantar. Writer use the desain research that is field research and library research. Its population is teacher of Nursery School of Methodist Pematangsiantar with the amount 17 people. Method of data collecting with the interview, documentation, questionnaires steming from source of data of primary and secunder and analysed with the descriptive analysis qualitative and quantitative descriptive analysis.

Research hypothesis is discipline work to give the influence which are positive to teacher performance at Nursery School of Methodist Pematangsiantar. To measure the teacher performance (Y) And discipline work $(X)$, Writer propagate the questionnaires to teachers TK so that obtained a descriptive data qualitative and quantitative descriptive. Result of analysis show the positive influence of variable $X$ to variable $Y$ with the equation $\hat{Y}=15,30+0,7711 X$. Strength of two variable is very strong that is equal to 0,848. From explainable coefficient determinasi 71,9\% teacher performance explained by discipline work and 28,1\% explained by other dissimilar factor which is not discussed in this research. From result of processing and calculation of data questionnaires, Writer conclude that discipline work applied by a school have an effect on to create the teacher performance. This matter is proved mathematically through hypothesis test, where result test the $t_{\text {hit }}(5,25)>t_{\text {tab }}$ $(2,131)$. Teacher performance always have to be improved, so for that needed the effort discipline applying work continually.

Keywords: Discipline Work and Teacher Performance

\section{A. PENDAhuluan}

\section{Latar Belakang Masalah}

Taman Kanak-kanak

Methodist Pematangsiantar merupakan institusi pendidikan umum dengan tujuan dapat melanjutkan pendidikan $\mathrm{SD}$, yang memiliki ilmu yang akan diharapkan mengikuti pelajaran dengan mudah. Untuk mencapai tujuan tersebut perlu menerapkan berbagai aturan dan tata tertib yang tertulis maupun secara lisan dengan tujuan kebaikan Taman Kanak-kanak Methodist Pematangsiantar, dan untuk mendukung kebijakan tersebut segenap guru yang berada di naungan TK Methodist berusaha menampilkan hasil kinerja yang baik.

Pada perkembangan zaman yang semakin modern dan canggih ini kinerja merupakan salah satu faktor yang penting dalam suatu organisasi. Dimana keberhasilan suatu organisasi dipengaruhi oleh kinerja. Taman Kanak-kanak Methodist adalah salah satu sekolah swasta yang bergerak di bidang pendidikan. Mengingat yang dikelola oleh sekolah adalah pendidikan maka sekolah mengandalkan 
displin dan tanggung jawab. Oleh karena itu sekolah harus dikelola oleh sumber daya manusia yang memiliki integritas moral yang baik dan terpercaya.

Kinerja dapat disebabkan oleh berbagai faktor salah satunya adalah disiplin kerja. Disiplin kerja yang diterapkan di antaranya adalah kepatuhan terhadap jam kehadiran di sekolah dan menaati peraturan yang sudah ditetapkan sekolah agar tercipta suasana kerja yang baik, dan setiap peraturan dapat dilakukan dengan tertib.

Dalam hal ini guru memiliki semangat kerja yang berperan penuh untuk melakukan tugas dan tanggungjawabnya di dalam kelas dapat terlaksana dengan baik. Filosofi dalam hal disiplin preventif yang berupa meningkatkan frekuensi kehadiran guru yang bertujuan untuk mengingatkan setiap guru dengan peraturan-peraturan yang ada pada sekolah, dan disiplin korektif yang berupa pemberian teguran secara lisan maupun tertulis oleh atasan yang bertujuan untuk memperbaiki guru yang melanggar peraturan. TK Methodist melakukan disiplin kerja agar meningkatkan kinerja guru dalam perencanaan pembelajaran, pelaksanaan pembelajaran dan penilaian/evaluasi pembelajaran dalam menjalankan keguruannya, kehadiran di sekolah, dan sikap kooperatif (kerja sama).

\section{Rumusan Masalah}

a. Bagaimana gambaran disiplin kerja dan kinerja guru pada Taman Kanak-kanak Methodist Pematangsiantar?

b. Seberapa besar pengaruh disiplin kerja terhadap kinerja guru pada Taman Kanak-kanak Methodist Pematangsiantar?

\section{Tujuan Penelitian}

a. Untuk mengetahui gambaran disiplin kerja dan kinerja guru pada Taman Kanak-kanak Methodist Pematangsiantar.

b. Untuk mengetahui besarnya pengaruh disiplin kerja terhadap kinerja guru pada Taman Kanakkanak Methodist Pematangsiantar.

\section{Metode Penelitian}

Objek penelitian dalam hal ini adalah Taman Kanak-kanak Methodist Pematangsiantar yang beralamat Jalan Thamrin No. 8H Pematangsiantar. Populasi dari penelitian ini adalah guru pada Taman Kanak-kanak Methodist Pematangsiantar yang berjumlah 17 orang yang akan menjadi sampel sebagai responden untuk menjawab kuesioner yang disebarkan oleh penulis.

Adapun Desain penelitian yang digunakan dalam penulisan skripsi ini adalah Penelitian Kepustakaan (Library Research) dan Penelitian Lapangan (Field Research). Teknik pengumpulan data yang dilakukan penulis dalam penelitian ini adalah berupa Kuesioner, Wawancara dan Dokumentasi. Adapun jenis data yang digunakan dalam penelitian ini adalah jenis data kualitatif dan data kuantitatif. Hasil data yang diperoleh dari lapangan akan dianalisis secara deskriptif baik bersifat kualitatif dan kuantitatif.

\section{B. LANDASAN TEORI}

Manajemen merupakan proses pendayagunaan bahan baku dan sumber daya manusia untuk mencapai tujuan yang ditetapkan. Proses ini melibatkan organisasi, arahan organisasi, dan evaluasi orang-orang guna mencapai tujuan tersebut. Esensi manajemen adalah aktivitas bekerja melalui orang lain untuk meraih berbagai hasil. Melalui manajemen dilakukan proses pengintegrasian berbagai sumber daya dan tugas untuk mencapai berbagai tujuan organisasi.

Menurut Mondy (2008:4), manajemen SDM adalah pemanfaatan sejumlah individu untuk mencapai tujuan-tujuan organisasi. Sedangkan menurut Dessler (2006:5), manajemen sumber daya manusia adalah proses memperoleh, melatih, menilai dan memberikan kompensasi kepada karyawan, memperhatikan hubungan kerja mereka, kesehatan, keamanan, dan masalah keadilan. Dari pendapat di atas maka dapat diambil kesimpulan bahwa yang utama sekali dikelola adalah manusia bukan sumber daya yang lainnya. Keberhasilan pengelolaan organisasi dapat ditentukan oleh kegiatan pendayagunaan sumber daya manusia.

Fungsi Manajemen Sumber Daya Manusia merupakan dasar dari pencapaian tujuan dari suatu organisasi atau perusahaan. Menurut Veithzal (2005:15), Fungsi manajemen sumber daya manusia sama dengan fungsi manajemen umum yaitu fungsi manajerial dan fungsi operasional. Secara umum fungsi manajerial dibedakan atas:

1. Perencanaan (human resource planning) adalah merencanakan tenaga kerja agar sesuai dengan kebutuhan perusahaan yang efektif serta efisien dalam membantu terwujudnya tujuan.

2. Pengorganisasian adalah kegiatan untuk mengorganisasi semua karyawan dengan menetapkan pembagian kerja, hubungan kerja, delegasi wewenang, integrasi dan koordinasinya dalam bagan organisasi (Organization Chart).

3. Pengarahan adalah kegiatan mengarahkan semua karyawan agar mau bekerjasama dan bekerja secara efektif dan efisien dalam terwujudnya tujuan perusahaan, karyawan dan masyarakat.

4. Pengendalian adalah kegiatan mengendalikan semua karyawan agar mau menaati peraturanperaturan perusahaan dan mau bekerja sesuai rencana.

Sedangkan fungsi dari manajemen operasional adalah:

1. Pengadaan tenaga kerja

Pengadaan adalah proses penarikan, seleksi, penempatan, orientasi dan induksi untuk mendapatkan karyawan yang sesuai dengan kebutuhan perusahaan.

2. Pengembangan

Pengembangan adalah proses peningkatan ketrampilan teknis, teoristik, konseptual dan moral karyawan melalui pendidikan dan pelatihan.

3. Kompensasi 
Kompensasi adalah pemberian balas jasa langsung (Direct) dan tidak langsung (Indirect), uang atau barang kepada karyawan sebagai imbalan jasa yang diberikan perusahaan.

4. Pengintegrasian

Pengintegrasian adalah kegiatan untuk mempersatukan kepentingan perusahaan dan kebutuhan karyawan, agar tercipta kerja sama yang serasi dan saling menguntungkan.

5. Pemeliharaan

Pemeliharaan adalah kegiatan untuk memelihara atau meningkatkan kondisi fisik, mental dan loyalitas karyawan, agar mereka bekerja sama sampai masa pensiun.

6. Pemutusan hubungan kerja

Pemberhentian adalah putusnya hubungan kerja seseorang dari suatu perusahaan. Pemberhentian ini disebabkan oleh keinginan karyawan, keinginan perusahaan, kontrak kerja, pensiun dan sebab-sebab lainnya.

Disiplin kerja sangat dibutuhkan oleh setiap perusahaan, karena dengan suasana yang berdisiplin karyawan akan dapat menjalankan semua kegiatan yang telah direncanakan perusahaan dengan baik dalam rangka mewujudkan tujuan yang didinginkan perusahaan. Mangkunegara (2001:129), mengemukakan bahwa: dicipline is management action to enforce organization standarts". Disiplin kerja dapat diartikan sebagai pelaksanaan manajemen untuk memperteguh pedoman-pedoman organisasi. Sedangkan menurut Hasibuan (2003:193), Disiplin kerja adalah keadaan dan kesediaan seseorang menaati semua peraturan dan norma-norma sosial yang berlaku. Berdasarkan pendapat para ahli di atas maka dapat diambil kesimpulan bahwa disiplin kerja adalah suatu hal yang berhubungan dengan sikap mental yang direfleksikan dalam perbuatan individu maupun kelompok yang berupa kepatuhan atau ketaatan terhadap peraturan-peraturan yang telah ditetapkan pada suatu organisasi, baik itu yang tertulis maupun yang tidak tertulis, guna mempertegas acuan dan pedoman dari organisasi.

Menurut Saydam (2000:291), faktor-faktor yang mempengaruhi disiplin kerja adalah sebagai berikut:

1. Besar kecilnya pemberian kompensasi

2. Ada tidaknya keteladanan pemimpin dalam perusahaan

3. Ada tidaknya aturan pasti yang dapat dijadikan pegangan

4. Keberanian pemimpin dalam mengambil tindakan

5. Ada tidaknya pengawasan pimpinan

6. Ada tidaknya perhatian kepada para karyawan

7. Diciptakan kebiasaan-kebiasaan yang mendukung tegaknya disiplin

Armstrong dan Baron dalam Lie (2012:128) menyatakan bahwa kinerja merupakan hasil pekerjaan yang mempunyai hubungan kuat dengan tujuan strategis organisasi, kepuasan konsumen, dan memberikan kontribusi pada ekonomi. Robert dalam Lie (2012:128), menyatakan bahwa kinerja (performance) pada dasarnya adalah apa yang dilakukan atau tidak dilakukan oleh karyawan. Secara umum dapat dikatakan bahwa kinerja (performance) merupakan wujud atau keberhasilan pekerjaan seseorang atau organisasi dalam mencapai tujuannya. Dari beberapa definisi di atas maka dapat disimpulkan bahwa kinerja (performance) adalah apa yang telah dikerjakan oleh karyawan dihadapkan dengan tuntutan tugas. Penilaian kinerja karyawan merupakan bagian integral dari proses penilaian yang meliputi penerapan sasaran kinerja karyawan yang spesifik, terukur, memiliki tingkat perubahan, terbatas waktunya.

Indikator-indikator kinerja dari berbagai ahli berbeda-beda, namun pada prinsipnya terdapat kesamaan. Menurut Martoyo dalam Lie (2012:132), penilaian kinerja karyawan adalah proses dimana organisasi-organisasi mengevaluasi atau menilai prestasi kerja karyawan. Apabila penilaian tentang prestasi kerja karyawan tersebut dilaksanakan dengan baik, tertib, dan benar, maka dapat membantu meningkatkan motivasi kerja dan sekaligus juga meningkatkan loyalitas organisasi dari para karyawan (anggota organisasi).

Guru merupakan bagian penting dalam pendidikan dan memegang peranan penting dalam usaha pencapaian tujuan pendidikan. Oleh karena itu perhatian suatu sekolah terhadap kinerja guru sangatlah penting. Kinerja guru merupakan gambaran hasil lulusan yang dicapai seseorang dalam jangka waktu tertentu. Kinerja atau performance pada dasarnya merupakan prestasi kerja, pelaksanaan kerja, pencapaian kerja atau hasil kerja / unjuk kerja dalam suatu organisasi.

Khusus untuk guru, ukuran kinerja guru terlihat dari rasa tanggung jawabnya menjalankan amanah, profesi yang diembannya, rasa tanggung jawab moral di pundaknya. Semua ini akan terlihat kepada kepatuhan dan loyalitasnya di dalam menjalankan tugas keguruannya di dalam kelas dan tugas kependidikannya di luar kelas. Sikap ini akan dibarengi pula dengan rasa tanggungjawabnya mempersiapkan segala perlengkapan pengajaran sebelum melaksanakan proses pembelajaran. Selain itu, guru juga sudah mempertimbangkan akan metodologi yang digunakan, termasuk alat, media pendidikan yang akan dipakai, serta alat penilaian apa yang digunakan di dalam pelaksanaan evaluasi.

\section{PEMBAHASAN}

\section{a. Deskriptif Kualitatif}

Analisis Deskriptif dimaksudkan untuk mendapatkan gambaran/deskripsi mengenai tanggapan dari responden mengenai disiplin kerja dan kinerja guru pada Taman Kanak-kanak Methodist Pematangsiantar. Sesudah pengujian data, maka langkah selanjutnya adalah peneliti melakukan pengkajian analisis kualitatif sebagai gambaran fenomenal dari variabel penelitian pada saat sekarang ini.

Adapun penetapan kriteria nilai data-data jawaban dari responden tersebut dimasukkan ke 
dalam kelas-kelas interval, dimana penentuan intervalnya menggunakan rumus sebagai berikut: panjang kelas $=\frac{\text { data terbesar }- \text { data terkecil }}{\text { jumlah kelas interval }}$

Keterangan: Nilai tertinggi adalah 5, Nilai terendah adalah 1, dan jumlah kelas adalah 5. Dari rumus di atas, diperoleh nilai interval kelas $=0,8$, sehingga berlaku ketentuan kategori dengan hasil sebagai berikut:

Tabel 1

Nilai Interval dan Kategori Jawaban Responden

\begin{tabular}{|c|c|}
\hline Nilai Interval & Kategori \\
\hline $1,00-1,80$ & SR (Sangat Rendah) \\
\hline $1,81-2,60$ & $\mathrm{R}$ (Rendah) \\
\hline $2,61-3,40$ & $\mathrm{C}$ (Cukup) \\
\hline $3,41-4,20$ & T (Tinggi) \\
\hline $4,21-5,00$ & ST (Sangat Tinggi) \\
\hline
\end{tabular}

Sumber : Data diolah

\section{1) Disiplin Kerja}

Dengan adanya penerapan disiplin kerja pada Taman Kanak-kanak Methodist Pematangsiantar diharapkan kinerja guru mengalami peningkatan yang cukup baik sehingga tujuan pembelajaran di sekolah dapat tercapai. Dengan disiplin kerja yang tertib karyawan akan termotivasi untuk melakukannya apabila disiplin kerja terus diterapkan dan ditingkatkan dalam pelaksanaannya di lingkungan kerja.

Mayoritas responden melakukan disiplin kerja untuk memenuhi peraturan kerja yang ditetapkan sekolah. Hal ini dinyatakan oleh 9 orang responden $(52,94 \%)$ yang memberi tanggapan sangat tinggi. Pernyataan tinggi dipilih oleh sebanyak 7 responden $(41,18 \%)$ dan 1 responden $(5,88 \%)$ menyatakan cukup tinggi. Mayoritas responden menyatakan cukup tinggi pada pertanyaan ini, karena dalam disiplin preventif sangat berpengaruh dalam mengajar yaitu ketepatan waktu dalam mengajar.

Untuk pertanyaan mengenai ketepatan waktu dalam mematuhi jam kerja, jika guru-guru mematuhi jam kerja sesuai dengan waktu yang sudah ditentukan, ada 9 responden $(52,94 \%)$ menyatakan sangat tinggi dan 6 respondeng $(35,29 \%)$ menyatakan cukup tinggi dan 2 responden $(11,77 \%)$ menyatakan cukup tinggi. Dengan demikian nilai rata-rata responden adalah 4,41 dengan kriteria sangat tinggi. Dalam hal ini guru-guru sangat disiplin dalam mematuhi jam kerja.

Dalam menerapkan disiplin kerja yang maksimal bagi guru, Taman Kanak-kanak Methodist Pematangsiantar menerapkan selalu berpakaian rapi dalam mengajar. Dimana sebanyak 12 responden $(70,58 \%)$ menyatakan sangat tinggi terhadap hal ini, 3 responden $(17,65 \%)$ menyatakan tinggi dan 2 orang responden $(11,77 \%)$ menyatakan cukup tinggi dalam hal ini. Sebagian besar responden sangat tinggi pada pertanyaan ini, selalu berpakaian rapi dalam mengajar. Dengan demikian nilai rata-rata responden adalah 4,59 dengan kriteria sangat tinggi.
Dari pertanyaan diatas ditunjukkan 11 responden $(64,70 \%)$ menyatakan sangat tinggi bahwa guru akan melaksanakan perintah yang diberikan kepala sekolah. Terdapat 3 responden $(17,65 \%)$ menyatakan tinggi bahwa guru akan melaksanakan perintah yang diberikan kepala sekolah. Selanjutnya 3 responden $(17,65 \%)$ menyatakan cukup tinggi bahwa guru akan melaksanakan perintah yang diberikan kepala sekolah. Dengan demikian nilai rata-rata responden adalah 4,47 .

8 responden $(47,06 \%)$ menyatakan sangat tinggi yaitu bertanggung jawab dengan pekerjaan yang saya emban di dalam kelas. Terdapat 5 responden $(29,41 \%)$ menyatakan tinggi yaitu bertanggung jawab dengan pekerjaan yang saya emban di dalam kelas. Selanjutnya 4 responden $(23,53 \%)$ menyatakan cukup tinggi yaitu bertanggung jawab dengan pekerjaan yang saya emban di dalam kelas. Dengan demikian nilai ratarata responden adalah 4,23 dengan kriteria sangat tinggi.

7 responden $(41,18 \%)$ menyatakan sangat tinggi dalam menyelesaikan pekerjaan dengan tepat waktu. Sebanyak 8 responden $(47,06 \%)$ menyatakan tinggi dalam menyelesaikan pekerjaan dengan tepat waktu. 2 responden $(11,76 \%)$ menyatakan cukup tinggi dalam menyelesaikan pekerjaan dengan tepat waktu. Dengan demikian nilai rata-rata responden adalah 4,29 dengan kriteria jawaban tinggi

Pada pertanyaan mengenai mendapatkan sanksi jika melanggar peraturan terdapat 9 responden $(52,94 \%)$ menyatakan sangat tinggi, dan 4 responden $(23,54 \%)$ menyatakan tinggi pada pertanyaan mengenai sanksi jika melanggar peraturan. Sebanyak 2 responden $(11,76 \%)$ menyatakan cukup tinggi pada pertanyaan mengenai sanksi jika melanggar peraturan. Dengan demikian nilai rata-rata responden adalah 4,17 dengan kriteria jawaban sangat tinggi.

Dari pertanyaan mengenai selalu menaati peraturan yang ada di lingkungan sekolah terdapat 7 responden $(41,18 \%)$ menyatakan sangat tinggi dan 9 reponden $(52.94 \%)$ memilih tinggi pada pertanyaan selalu menaati peraturan yang ada di sekolah.sebanyak 1 responden memilih cukup rendah pada pertanyaan selalu menaati peraturan yang ada di lingkungan sekolah. Dengan demikian nilai rata-rata responden adalah 4,53 dengan kriteria jawaban tinggi.

Tidak meminta ijin jika tidak masuk kerja terdapat 4 responden $(23,53 \%)$ memilih sangat tinggi. 4 responden $(23,53 \%)$ memilih tinggi pada pertanyaan tidak meminta ijin jika tidak masuk kerja. Terdapat 1 responden $(5,88 \%)$ memilih rendah pada pertanyaan tidak meminta ijin jika tidak masuk kerja. Sebanyak 8 responden $(47,06 \%)$ memilih sangat rendah pada pertanyaan tidak meminta ijin jika tidak masuk kerja. Dengan demikian nilai ratarata responden adalah 2,71 dengan kriteria jawaban sangat rendah. 


\section{2) Kinerja Guru}

Berdasarkan data tanggapan responden dapat diketahui 10 responden $(58,82 \%)$ memilih jawaban sangat tinggi hal ini dikarenakan responden melakukan pengembangan silabus dengan baik. 3 responden $(17,65 \%)$ memilih tinggi pada pertanyaan bagaimana kemampuan guru dalam mengembangkan silabus. 4 responden $(23,53 \%)$ memilih cukup tinggi atas pertanyaan bagaimana kemampuan guru dalam mengembangkan silabus. Dengan demikian nilai rata-rata responden adalah 4,35 dengan kriteria jawaban sangat tinggi.

6 responden $(35,30 \%)$ memilih sangat tinggi atas pertanyaan bagaimana kemampuan guru dalam penyusunan rencana pelaksanaan pembelajaran. 3 responden $(17,64 \%)$ memilih tinggi atas pertanyaan bagaimana kemampuan guru dalam penyusunan rencana pelaksanaan pembelajaran. Sebanyak 8 responden $(47,06 \%)$ memilih jawaban cukup tinggi atas pertanyaan bagaimana kemampuan guru dalam penyusunan rencana pelaksanaan pembelajaran. Dengan demikian nilai rata-rata responden adalah 3,88 dengan kriteria jawaban cukup tinggi.

Dari data responden yang memberikan jawaban atas pertanyaan bagaimana kemampuan guru dalam penggunaan media pembelajaran 14 responden $(82,35 \%)$ dengan jawaban sangat tinggi. 3 responden $(17,65 \%)$ memilih jawaban tinggi atas pertanyaan bagaimana kemampuan guru dalam penggunaan media pembelajaran. Dengan demikian nilai rata-rata responden adalah 4,82 dengan kriteria jawaban sangat tinggi

Dari data tanggapan responden diperoleh hasil 11 responden $(64,70 \%)$ memilih sangat tinggi atas pertanyaan bagaimana kinerja guru dalam pelaksanaan pembelajaran, dan 3 responden $(17,65 \%)$ memilih jawaban tinggi atas pertanyaan bagaimana kinerja guru dalam pelaksanaan pembelajaran. Selanjutnya 3 responden $(17,65 \%)$ memilih jawaban cukup tinggi atas pertanyaan bagaimana kinerja guru dalam pelaksanaan pembelajaran. Dengan demikian nilai rata-rata responden adalah 4,47 dengan kriteria jawaban sangat tinggi.

Dari data tanggapan responden dapat dilihat bahwa kinerja guru dalam penggunaan metode pembelajaran ada 8 responden $(47,06 \%)$ memilih sangat tinggi. 5 reponden $(29,41 \%)$ memilih jawaban tinggi atas pertanyaan bahwa kinerja guru dalam penggunaan metode pembelajaran. Selanjutnya 4 responden $(23,53 \%)$ memilih jawaban cukup tinggi atas pertanyaan bagaimana kinerja guru dalam penggunaan metode pembelajaran. Dengan demikian nilai rata-rata responden adalah 4,23 dengan kriteria jawaban sangat tinggi.

Dari data tanggapan responden diperoleh hasil data yaitu 7 responden $(41,18 \%)$ memilih jawaban sangat tinggi atas pertanyaan bagaimana kinerja guru dalam penggunaan strategi pembelajaran. Sebanyak 8 responden $(47,06 \%)$ memilih jawaban tinggi atas pertanyaan bagaimana kinerja guru dalam penggunaan strategi pembelajaran. Selanjutnya 2 responden $(11,76 \%)$ responden memiliha jawaban cukup tinggi atas pertanyaan bagaimana kinerja guru dalam penggunaan strategi pembelajaran. Dengan demikian nilai rata-rata responden adalah 4,29 dengan kriteria jawaban tinggi

\section{b. Deskriptif Kuantitatif}

\section{1) Analisa Regresi Linear Sederhana}

Dalam analisis deskriptif kuantitatif, penulis menganalisis besarnya pengaruh antara disiplin kerja (X) dan terhadap kinerja guru (Y) melalui analisis regresi. Selanjutnya adalah melakukan analisis korelasi untuk mengukur kuatnya hubungan antara dua variabel atau lebih.

Pada penelitian ini dibahas tentang pengaruh disiplin kerja terhadap kinerja guru. Variabel penelitian terdiri dari variabel bebas $(\mathrm{X})$ dan variabel terikat (Y). Adapun persamaan regresinya adalah sebagai berikut :

$$
\hat{Y}=a+b X
$$

Dimana: $\quad X=$ Variabel Bebas (Disiplin Kerja)

$\mathrm{Y}=$ Variabel Terikat (Kinerja Guru)

$\mathrm{a}=$ Konstanta

b = Koefisien Regresi

Untuk mengetahui pengaruh disiplin kerja terhadap kinerja guru maka dilakukan perhitungan secara manual untuk memperoleh nilai a dan b, yaitu:

$$
\begin{aligned}
& \mathrm{a}=\left(\sum Y-b \sum X\right) / \mathrm{n} \\
& \mathrm{b}=\frac{\pi \sum X Y-\left(\sum X\right)\left(\sum Y\right)}{n \sum X^{2}-\left(\sum x\right)^{2}} \\
& \mathrm{~b}=\frac{(17)(21.265)-(533)(671)}{(17)(17.007)-(533)^{2}} \\
& \mathrm{~b}=\frac{3.879}{5030} \\
& \mathbf{b}=\mathbf{0 , 7 7 1 1}
\end{aligned}
$$
berikut :

Selanjutnya, menentukan koefisien a, sebagai $a=[(671)-(0,7711)(533)] / 17$ $\mathrm{a}=\mathbf{1 5 , 3 0}$

Maka model regresi liniernya menjadi: $\hat{\mathbf{Y}}=\mathbf{1 5}, \mathbf{3 0 + 0 , 7 7 1 1 X}$

Jadi dari persamaan regresinya $\hat{Y}=15,30+0,7711 X$, maka dapat diartikan bahwa disiplin kerja berpengaruh positif pada kinerja guru. Dimana jika pelaksanaan disiplin kerja semakin baik, maka kinerja guru yang tercipta semakin tinggi pula.

\section{2) Korelasi dan Koefisien Determinasi}

Setelah mengetahui persamaan linier selanjutnya adalah mencari korelasi dengan persamaan berikut :

$$
\begin{aligned}
& r=\frac{n\left(\sum X Y\right)-\left(\sum X\right)\left(\sum Y\right)}{\sqrt{n \sum X^{2}-\left(\sum X\right)^{2} \sqrt{n \sum Y^{2}-\left(\sum Y\right)^{2}}}} \\
& r=\frac{17(21.266)-(533)(671)}{\sqrt{17(17.007)-(533)^{2}} \sqrt{17(26.729)(671)^{2}}} \\
& r=\frac{361.522-357.643}{\sqrt{289.119-284.089} \sqrt{454.393-450.241}} \\
& r=\frac{3.879}{\sqrt{(5.030)(4152)}} \\
& r=\frac{3.879}{4.569 .96} \\
& \mathbf{r}=\mathbf{0 . 8 4 8}
\end{aligned}
$$


Dari hasil perhitungan di atas, dapat diketahui bahwa terdapat hubungan yang sangat kuat dan positif antara Disiplin kerja terhadap kinerja guru pada Taman Kanak-kanak Methodist Pematangsiantar.

Adapun koefisien determinasinya adalah sebagai berikut:

$\mathrm{R}=r^{2} \times 100 \%$

$\mathrm{R}=(0.848)^{2} \times 100 \%$

$\mathrm{R}=0,719 \times 100 \%$

$\mathrm{R}=71,9 \%$

Dari perhitungan di atas, dapat dilihat bahwa disiplin kerja menjelaskan tinggi rendahnya kinerja guru yaitu sebesar $71,9 \%$, sedangkan sisanya $28,1 \%$ dijelaskan oleh faktor lainnya seperti komitmen, gaya kepemimpinan, budaya organisasi lingkungan kerja dan sebagainya yang tidak dibahas dalam penelitian.

\section{3) Uji Hipotesis}

Selanjutnya menurut prinsip metode statistika, nilai regresi yang diperoleh harus diuji terlebih dahulu untuk menyatakan apakah nilainya signifikan atau tidak. Caranya adalah menguji koefisien regresi dengan menggunakan "sebaran t" dengan mendistribusikan nilai $\mathrm{r}$ yang diperoleh ke dalam persamaan t, untuk mengukur taraf signifikannya. Hipotesis dalam penelitian ini adalah: Ho $=0$ : bahwa disiplin kerja tidak berpengaruh positif terhadap kinerja guru pada Taman Kanakkanak Methodist Pematangsiantar.

$\mathrm{Ha}=0$ : bahwa disiplin kerja berpengaruh positif terhadap kinerja guru pada Taman Kanak-kanak Mcthodist Pematangsiantar. berikut :

Dengan demikian dapat dihitung $t_{\text {hit }}$ sebagai

$$
\begin{aligned}
t_{\text {hit }} & =\frac{r \sqrt{\pi-2}}{\sqrt{1-r^{2}}} \\
t_{\text {hit }} & =\frac{0,848 \sqrt{17-2}}{\sqrt{1-0.719}} \\
t_{\text {hit }} & =\frac{2.7846}{0.530} \\
t_{\text {hit }} & =5,25
\end{aligned}
$$

Oleh karena $t_{\text {hitung }}(5,25)>t_{\text {tabel }}(2,131)$ maka $H_{0}$ ditolak dan $H_{a}$ diterima, artinya variabel disiplin kerja (X) bespengaruh secara positif terhadap variabel kinerja guru (Y). Hal ini berarti bahwa disiplin kerja akan berpengaruh terhadap kinerja guru pada Taman Kanak-kanak Methodist Pematangsiantar, dengan demikian hipotesis yang diajukan penulis dapat diterima.

\section{Evaluasi}

\section{a. Disiplin Kerja}

Pada Taman Kanak-kanak Methodist Pematangsiantar guru yang melakukan pelanggaran indisipliner kehadiran di tempat kerja dan adanya hubungan yang tidak harmonis antara sesame guru dan kepala sekolah. Untuk meningkatkan kedua indikator diatas Taman Kanak-kanak Methodist Pematangsiantar melakukan penerapan disiplin kerja berupa disiplin preventif dan disiplin korektif, yang dimana disiplin preventif lebih berfokus kepada upaya untuk menggerakkan guru agar mengikuti dan mematuhi aturan-aturan yang telah ditetapkan oleh sekolah sehingga guru dapat mendisiplinkan diri sendiri.

Disiplin preventif bertujuan untuk mengingatkan guru dengan peraturan yang ada pada sekolah. Taman Kanak-kanak Methodist Pematangsiantar menerapkan disiplin preventif berupa frekuensi kehadiran, sanksi dan ketegasan, hubungan kemanusiaan serta balas jasa.

Sedangkan untuk disiplin korektif merupakan disiplin yang berfokus terhadap pemberian sanksi dan efek jera kepada guru yang melanggar disiplin, sehingga guru yang melanggar disiplin diberikan sanksi sesuai dengan peraturan yang berlaku. Tujuan pemberian sanksi adalah untuk memperbaiki guru yang melanggar peraturan, memelihara peraturan yang berlaku, dan member efek jera pada yang melanggar peraturan. Taman Kanak-kanak Methodist Pematangsiantar menerapkan disiplin korektif berupa teguran lisan dan tulisan oleh atasan.

Dengan menerapkan kedua disiplin tersebut dengan benar dapat dipastikan pelanggaran indisipliner yang dilakukan oleh guru tidak akan terulang kembali, dan ketika guru ingin melakukan pelanggaran indisipliner, guru akan berfikir dua kali untuk melakukannya.

\section{b. Kinerja Guru}

Guru merupakan bagian penting dalam pendidikan dan memegang peranan penting dalam usaha pencapaian tujuan pendidikan. Oleh karena itu perhatian suatu sekolah terhadap kinerja guru sangatlah penting. Kinerja guru merupakan gambaran hasil lulusan yang dicapai seseorang dalam jangka waktu tertentu. Kinerja atar performance pada dasarnya merupakan prestasi kerja, pelaksanaan kerja, pencapaian kerja atau hasil kerja / unjuk kerja dalam suatu organisasi.

Untuk meningkatkan kinerja guru Taman Kanak-kanak Methodist Pematangsiantar melakukan indikator penilaian terhadap tiga kegiatan pembelajaran di kelas, yaitu perencanaan program kegiatan pembelajaran, pelaksanaan kegiatan pembelajaran dan evaluasi / penilaian pembelajaran. Untuk meningkatkan kinerja guru Taman Kanakkanak Methodist Pematangsiantar melakukan disiplin preventif yang berupa meningkatkan frekuensi kehadiran guru di tempat kerja, dan disiplin korektif yang berupa pemberian teguran lisan maupun tertulis oleh kepala sekolah. Kedua disiplin kerja diatas diterapkan untuk meningkatkan kinerja guru pada indikator perencanaan program kegiatan pembelajaran, pelaksanaan kegiatan pembelajaran dan evaluasi / penilaian pembelajaran. Dengan menerapkan kedua disiplin kerja tersebut sekolah dapat meningkatkan kinerja guru dan tujuan sekolah dapat tercapai secara optimal. 


\section{KESIMPULAN DAN SARAN}

\section{Kesimpulan}

a. Dari hasil kuesioner yang dibagikan kepada guru-guru Taman Kanak-kanak Methodist Pematangsiantar, menunjukkan bahwa disiplin kerja guru di Taman Kanak-kanak Methodist Pematangsiantar berada dalam kriteria sangat tinggi yaitu ketepatan waktu dalam mengajar sebesar $(4,47)$. Akan tetapi disiplin minta ijin untuk tidak masuk kerja masih berada pada kriteria cukup yang dibagikan kepada guru-guru Taman Kanak-kanak Methodist Pematangsiantar.

b. Dari hasil kuesioner dapat dilihat bahwa penerapan disiplin kerja pada Taman Kanakkanak Methodist Pematangsiantar, menunjukkan bahwa kinerja berada pada kriteria sangat tinggi, akan tetapi kemampuan guru dalam menentukan cara-cara dan alat evaluasi masih dalam kriteria cukup. Dalam hal ini fasilitas yang disediakan sekolah masih terbatas, guru masih menggunakan alat bantu ajar seperti: buku pendukung, alat peraga, dan mengilustrasikan materi pelajarannya dengan menggunakan spidol pada papan tulis.

c. Disiplin kerja berpengaruh terhadap kinerja guru, hal ini dapat dilihat dari hasil pengujian regresi yang menunjukkan tanda positif pada persamaan berikut : $\hat{P}=15,30+0,7711 \mathrm{X}$, artinya semakin baik disiplin kerja yang diterapkan maka kinerja guru akan semakin baik.

d. Berdasarkan analisis koefisien determinasi diperoleh hasil koefisien regresi sebesar 0,848. Hal ini menunjukkan bahwa terdapat hubungan yang sangat kuat antara disiplin kerja dan kinerja guru. Kesimpulan ini dibuktikan dengan perhitungan koefisien determinasi sebesar $71,9 \%$ yang berarti bahwa disiplin kerja menjelaskan tinggi rendahnya kinerja guru dan sisanya $28,1 \%$ adalah dijelaskan oleh faktor lain seperti komitmen, gaya kepemimpinan, budaya organisasi, lingkungan kerja dan sebagainya yang tidak dibahas dalam penelitian.

e. Hasil uji hipotesis menunjukkan bahwa koefisien korelasi $t_{\text {hit }}(5,25)>t_{\text {tab }}$ (2.131). Berarti variabel disiplin kerja berpengaruh positif terhadap kinerja guru, sehingga $H_{0}$ ditolak dan $H_{a}$ diterima, artinya disiplin kerja berpengaruh positif terhadap kinerja guru pada Taman Kanakkanak Methodist Pematangsiantar.

\section{Saran}

a. Agar kemampuan guru Taman Kanak-kanak Methodist Pematangsiantar mempunyai disiplin minta izin tidak masuk kerja, maka peraturan tata tertib dan peraturan kepegawaian harus dilaksanakan dengan konsekuensi dan kepala sekolah harus menegakkan disiplin tersebut.

b. Agar guru Taman Kanak-kanak Methodist Pematangsiantar mampu menentukan cara - cara dan alat evaluasi, maka pihak sekolah harus memberikan pelatihan dengan mendatangkan pakar/tenaga ahli untuk melatih para guru. Disamping itu para guru juga harus sering diikuti sertakan dalam seminar, workshop guru dan pertemuan-pertemuan ilmiah lainnya.

c. Sehubungan dengan keterbatasan - keterbatasan yang ada pada penulis, penelitian ini masih terdapat kelemahan dan belum dapat mengungkap seluruh variabel yang dapat mempengaruhi kinerja guru pada Taman Kanakkanak Methodist Pematangsiantar sebagai bahan masukan untuk peneliti selanjutnya, perlu memperbanyak variabel penelitian seperti motivasi, kepemimpinan, budaya organisasi dan prestasi kerja.

\section{E. DAFTAR PUSTAKA}

Dessler, Gary, 2006, Manajemen Sumber Daya Manusia, Jakarta : Penerbit PT Indeks.

Hasibuan, Malayu S. P, 2003, Manajemen Sumber Daya Manusia, Edisi Revisi, Jakarta : PT. Bumi Aksara.

Lie, Darwin, 2012, Analisis Pengaruh Kepemimpinan Kepala Sekolah, Budaya Organisasi Sekolah, Kompetensi Guru Terhadap Motivasi dan Komitmen Guru Serta Implikasinya Terhadap Kinerja Guru (Studi Kasus Pada SMA di Lima Kabupaten - Kota Provinsi Sumatera Utara), Bandung : Universitas Pasundan. Disertasi.

Mangkunegara, A. A. Anwar Prabu, 2001, Manajemen Sumber Daya Manusia Perusahaan, Bandung : PT.Remaja Rosda Karya.

Mondy, R, Wayen, 2008, Manajemen Sumber Daya Manusia, Jakarta : Penerbit Erlangga.

Saydam, Gouzali, 2000, Manajemen Sumber Daya Manusia, Jakarta : PT. Toko Gunung Agung.

Veithzal, Rivai, 2005, Manajemen Sumber Daya Manusia Untuk Perusahaan, Jakarta : PT. Raja Grafindo Persada. 